\title{
Materializing the blue economy: tuna fisheries and the theory of access in the Western Indian Ocean
}

\author{
Mialy Andriamahefazafy ${ }^{1}$ \\ Christian A. Kull
}

University of Lausanne, Switzerland

\begin{abstract}
Many African countries are progressively embracing the blue economy. African islands of the western Indian Ocean, however, have been involved in it for more than twenty years through the exploitation of their 'blue gold': tuna. In this article, we use Ribot and Peluso's (2003) "theory of access" to map the different ways actors access tuna under diverse socio-economic contexts and how power relations are created through different mechanisms of access. We show that rights-based mechanisms such as fishing access agreements are highly questionable for their fairness and sustainability but bring benefits such as funding for fisheries-related infrastructures and projects. We also show that access to the resource is dependent on knowledge held by fishers, on technological advances as well as on diverse labor relations. These mechanisms significantly impact the quantity of fish that can be accessed by artisanal versus industrial market sectors, and generate narratives of unequal access to tuna. Furthermore, we take into consideration the materiality of tuna as a highly mobile resource in a space of fluid boundaries, to show how the fish can be an actant in shaping access but also how fishing practices can produce new materialities. Based on the above evidence, we propose an enhancement of the theory of access to consider the role of materiality of the resources and the sea. We conclude that to ensure that tuna fisheries continue to contribute to the blue economy of African islands, stakeholders need to balance between the diverse benefits produced by the fisheries and the uneven power relations that can arise, and to integrate the impact of a material sea and fish in this reflection.
\end{abstract}

Keywords: fishers, knowledge, materiality, power relations, spatiality of the sea, technology, Madagascar, Mauritius, Seychelles

\section{Résumé}

De nombreux pays africains adoptent progressivement le concept d'économie bleue. Les îles africaines de l'océan Indien occidental pourtant y contribuent depuis plus de vingt ans grâce à l'exploitation de leur «or bleu»: le thon. Dans cet article, nous utilisons la théorie de l'accès de Ribot et Peluso (2003) pour cartographier les différents mécanismes d'accès au thon dans des contextes socio-économiques différents et pour mettre en évidence les relations de pouvoir qui se créent à travers ces mécanismes. Nous montrons que les mécanismes fondés sur le droit, tels que les accords de pêche, sont hautement discutables pour leur équité et durabilité, mais sont aussi source de bénéfices divers dans des pays hôtes principalement par l'octroi de financement pour les infrastructures et projets liés à la pêche. Nous montrons également que l'accès à la ressource dépend des connaissances des pêcheurs, des progrès technologiques et de diverses relations de travail. Ces mécanismes ont un impact non-négligeable sur la quantité de poisson accessible par les secteurs artisanaux et industriels, et génèrent des discours sur l'inégalité d'accès au thon. Compte tenu de la spécificité du thon étant une ressource hautement mobile, nous utilisons le concept de matérialité pour montrer comment

\footnotetext{
${ }^{1}$ Mialy Andriamahefazafy, PhD Candidate and Christian A. Kull, Professor, Faculty of Geosciences and Environment, University of Lausanne, Switzerland. Emails: mialyzanah.andriamahefazafy "at" unil.ch and christian.kull "at" unil.ch. Acknowledgements: We are grateful to all the interviewees that shared their valuable perspectives with us as well as Safina Echa, Pamima Leste and Patsy Theresine whose key contributions as research assistants during the fieldwork have been much appreciated. We would like to thank Liam Campling, Valérie Boisvert, Christina Hicks and John Childs for comments on the earlier drafts of the article. Thanks also to the editors of the Journal of Political Ecology and the anonymous reviewers for their thoughtful and helpful comments. We acknowledge the Institute of Geography and Sustainability of the University of Lausanne for having financially supported the fieldwork. This is the fourth article in John Childs and Christina Hicks (eds.). 2019. "Political ecologies of the blue economy in Africa", Special Section of the Journal of Political Ecology 26: 323-465.
} 
le poisson peut jouer un rôle dans la structuration de l'accès, mais aussi comment les pratiques de pêche peuvent produire de nouvelles matérialités. Sur la base des éléments ci-dessus, et afin de mieux comprendre l'importance de l'action des ressources en mouvement telles que le thon dans des espaces aux frontières fluides telles que la mer, nous proposons une amélioration de la théorie de l'accès consistant à donner plus d'importance au rôle de la matérialité des ressources et de la mer. Nous concluons que pour que la pêche thonière continue à contribuer à l'économie bleue des îles africaines, les parties prenantes doivent trouver un équilibre entre les divers avantages produits par cette pêcherie et les relations de pouvoir inégales, ainsi qu'intégrer l'impact de la matérialité des ressources dans cette réflexion.

Mots-clés : pêcheurs, savoir, matérialité, relations de pouvoir, spatialité de la mer, technologie, Madagascar, Ile Maurice, Seychelles

\section{Resumen}

Muchos países africanos han empezado de adoptar la "economía azul". Islas africanas del Océano Índico Occidental participan en ella desde hace más de veinte años gracias a la utilización de su oro azul: el atún. En este artículo, usamos la teoría del acceso de Ribot y Peluso (2003) para cartografiar las variadas maneras en aquellas el atún esta accedido al amparo de diferente contextos sociales y económicos, y para examinar como diferentes mecanismos de acceso generan variadas relaciones de poder. Demostramos que los mecanismos fundados sobre los derechos, como los acuerdos de acceso a la pesca, son cuestionables con respecto a su equidad y su sostenibilidad, aunque benefician a los países anfitriones gracias al financiamiento de infraestructuras y proyectos relatados a la pesca. Demostramos también que el acceso al recurso depende del saber de los pescadores, del progreso tecnológico, y de variadas relaciones de trabajo. Esos mecanismos tienen un efecto mayor sobre la cuantidad de pescado que los mercados artesanal versus industrial pueden acceder, y generan narraciones de acceso desigual al atún. Teniendo en cuenta la especificidad del atún, que es un recurso muy movible, usamos la materialidad para demostrar como el pescado puede ser un actant que influye en su acceso y también como prácticas de pesca pueden producir materialidades nuevas Basándonos en esas pruebas, y con el objetivo de entender mejor la importancia de las acciones de los recursos movibles como el atún en los espacios de fronteras fluidas como el mar, proponemos un aumento de la teoría del acceso, que tenga en cuenta la función de la materialidad del recurso y del mar. Concluimos que para asegurar que la industria pesquera del atún sigue contribuyendo a la economía azul de las islas africanas, sus protagonistas tienen que mantener el equilibrio entre los beneficios variados de las industrias pesqueras y las desiguales relaciones de poder que pueden aparecer, y que integrar la materialidad del mar y del pescado en su pensamiento.

Palabras Clave: pescadores, saber, materialidad, relaciones de poder, espacialidad del mar, tecnología, Madagascar, La isla Mauricio, Seychelles

\section{Introduction}

Tuna fisheries are one of the most valuable fisheries in the world (Campling 2012a; Pew 2016). In 2014, tuna's contribution to the global economy was estimated at more than US\$42 billion (Pew 2016). The Indian Ocean generates US\$2 billion from its tuna, of which up to $80 \%$ comes from the Western Indian Ocean (WIO) (Obura et al. 2017). Tuna fisheries are considered a key component for the emergent blue economy of Africa and especially the WIO region. They are providing important revenues, jobs, and food security for coastal communities. Industrial fisheries, focused largely on tuna and mainly undertaken by distant water fishing nations (DWFNs), are the third income provider in the WIO blue economy (after coastal and marine tourism and carbon sequestration). Small-scale fisheries provide livelihoods and food for coastal communities at an often underestimated value of US $\$ 200$ million (Obura et al. 2017). The management of fisheries depends on interactions between various stakeholders at different scales, from local fishing villages and ports, to national governments, to the regional Indian Ocean level and NGOs. Management is complicated by the fact that tuna is a multi-species resource that moves between territorial waters, exclusive economic zones and the high seas. This leads to intricate relations of access to the resources between actors but also between actors and the moving tuna. 
This article presents an approach that allows us to show these different interactions in the fisheries in one frame. It does so by applying the 'theory of access' developed by Ribot and Peluso (2003) to the tuna question. By approaching the tuna fishery question through the angle of resource access, one is forced to consider multiple aspects, including the multiplicity of actors involved, their interactions over resource access, the array of benefit streams from the resource, and, crucially the role of the fish and their ecology in this access. The advantage of such an approach is that alternative entry points can be suggested when analyzing resource use and management. The goal of the article is twofold. First, we offer a better understanding of the diversity of ways in which tuna resources are accessed and the power negotiations that take place between actors in this process while having a common goal of better management of tuna and sustainability of the resources. Second, we propose to adapt and refine the theory of access, largely conceived with stationary terrestrial resources in mind, by taking into consideration the materiality of tuna and the spatiality of the ocean. By explicitly grafting materiality and spatiality to the theory of access, it can better analyze access to moving resources. As in the case of other moving resources, such as migratory wildlife, the specificities of the species, their ecological features, the socio-political and ecological environment in which they live, and the practices of exploitation and management create a dynamic, hybrid, spatialized materiality that influence the processes of access.

The article starts with a brief presentation of the 'theory of access' by Ribot and Peluso, and how we understand it. The relevance of integrating materiality into a theory of access for tuna fisheries is also presented. We then apply the theory to the case of tuna resources in the WIO region, analyzing rights-based mechanisms and three specific structural and relational mechanisms: knowledge, technology and the social relations of labor. To expand more on the role of materiality, we provide examples of how this influences the politics of access. The implications of the study are significant in the current context of the 'Blue Economy', which we understand as a frontier concept, gathering various stakeholders ranging from businesses promoting ocean-based private sector interventions, to small-scale actors claiming access rights and governments advocating for a sustainable blue growth (Childs and Hicks 2019; Hinder and Le Heron 2017; Silver et al. 2015). Examining access to tuna and the role of materiality allows us to highlight the biological and socioeconomic processes at play between these blue economy actors and resources. The article also explores the role of a moving commodity in the ocean space, where sites of production involve both large and small-scale actors.

\section{Study sites and methods}

The western Indian Ocean region is typically considered to include the territorial waters and exclusive economic zones (EEZs) of 15 countries as well as a large area of open sea (Figure 1). Due to upwelling along coastal areas and energetic eddy processes, the WIO is an area of biological productivity, favorable for tuna species (Dagorn 1994). The region hosts eight main tuna species, of which four are considered key commercial species: skipjack tuna (Katsuwonus pelamis), yellowfin tuna (Thunus albacares), albacore (Thunus alalunga) and bigeye tuna (Thunus obesus). The other species are considered coastal tuna mainly caught by small-scale artisanal fishing (POSEIDON et al. 2014).

The different species occupy several ecological niches, as various species have preferences for different depths - from surface waters to $500 \mathrm{~m}$ depth - and for coastal proximity versus open ocean. They also diverge in dietary specialties, though most do prey on other small fishes, crustaceans, cephalopods and mollusks (Collette et al. 2011; Froese et al. 2012). While coastal tuna (kawakawa, frigate, and longtail tuna) are more sedentary, the key commercial species are quite mobile, migrating around the region and beyond in search of food and suitable environments (Dagorn 1994; Gillett 2011; Nikolic et al. 2014).

Tuna fisheries can be classified into three types: industrial fisheries, small-scale fisheries and a socalled 'semi-industrial' longline fishery. While the industrial fishery is largely owned by third party countries, also known as 'distant water fishing nations' (DWFNs), the small scale and semi-industrial fishery originates in the WIO countries (Le Manach 2014; POSEIDON et al. 2014). 


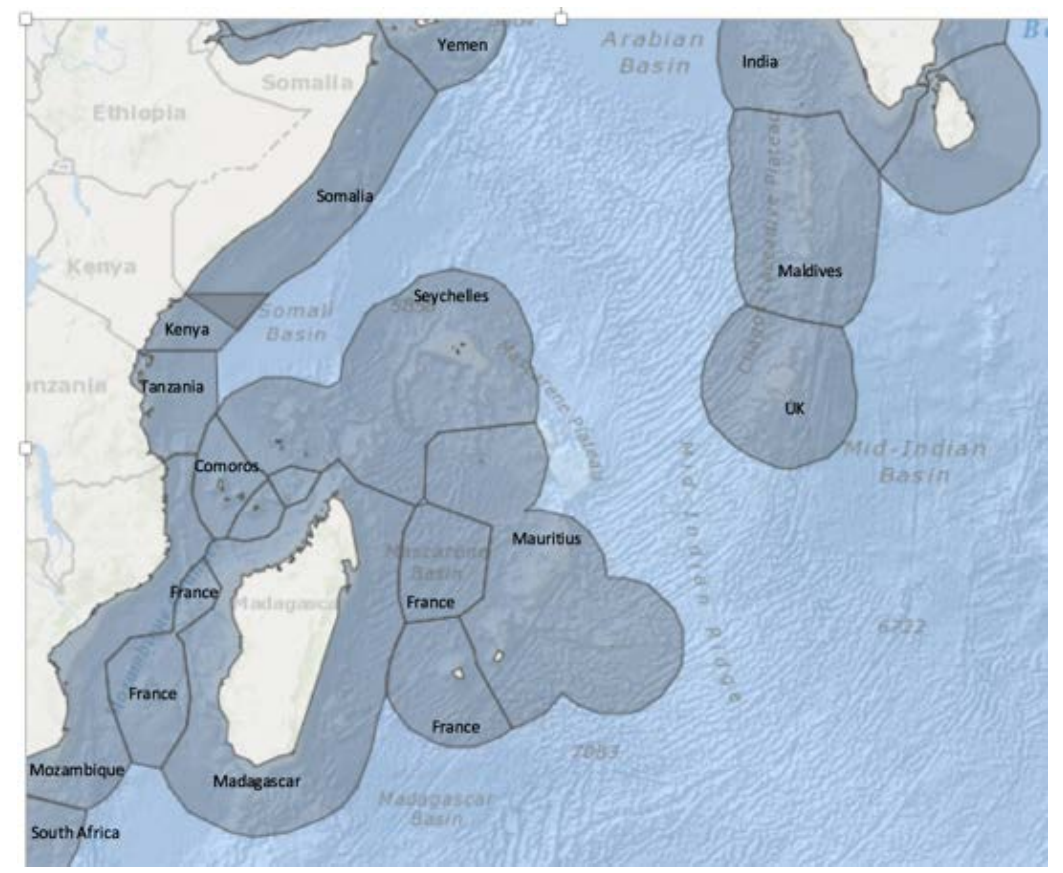

Figure 1: Map of the Exclusive Economic Zones (EEZs) of the countries of the WIO region. Source: Adapted by the authors from the "Sea Around Us" project http://www.seaaroundus.org/data/\#/eez

The present study focuses on three countries, Madagascar, Mauritius and Seychelles. Despite being close to each other at the center of the WIO tuna fishery - each having active fishing ports and canneries - the three countries have very distinctive socio-economic and historical contexts and different levels of exploitation of tuna resources. In Madagascar, the contribution of tuna fisheries to the economy is considered less than $10 \%$ of the GDP (it is focused more on agricultural cash crops) despite a yearly 15,000 tons of production (Breuil and Grima 2014). The country has an under-developed national tuna fishery mostly composed of small-scale coastal fishing and a handful of semi-industrial boats. In Mauritius, the fishery's production of around 4,000 tons/year contributes to less than 2\% of the GDP and constitutes around 20\% of exports (COFREPECHE et al. 2016; GoMU 2017). The tuna fishery is more developed than in Madagascar with a better-equipped small-scale fishery and a larger national semi-industrial fleet. Mauritius also hosts the main transshipment port for longliners operating in regional waters. In Seychelles, tuna fisheries are at the center of the economy (Schutter and Hicks 2019). In 2011, tuna fisheries contributed to approximately 20\% of the GDP as well as more than 90\% of exports (Marsac et al. 2014). Seychelles has an important national semi-industrial tuna fleet and a small-scale fishery that also catches tuna, without targeting it. In 2015, the tuna catch in the Seychelles' EEZ was estimated at around 60,000 tons (SFA 2016). Seychelles plays a key role in the tuna fisheries of the WIO, having the most important port for the purse seine vessels to land and transship as well as being in the middle of tuna fishing grounds. The three countries all host industrial fishing by European and Asian fleets. In fact, the Spanish and French fleets have dominated the catch since their arrival in the WIO in the 1980s, when the WIO was the "last commodity frontier" for tuna (Campling 2012a). Socio-economically, Madagascar is much poorer than its two neighbors, with a Human Development Index ranking of 154 (out of 188 countries), while Seychelles and Mauritius are classified as countries with high human development, ranked respectively at 63 and 64 (UNDP 2016). While tuna fisheries have a more important place in Seychelles' economy compared to Mauritius, the latter's GDP is almost 10 times higher than its Seychellois neighbor, mainly through its developed tertiary sector (Sellström 2015; UNDP 2016). 
The research draws on an empirical approach consisting of three main methods. First, the lead author gathered the perspectives of stakeholders regarding access to tuna through semi-structured interviews undertaken in 2017, with 86 fishers (61 small scale, 11 industrial and 14 semi-industrial), 40 government officials, 7 cannery staff members and 18 NGO representatives in Madagascar (interviews coded as MD), Mauritius (coded as MU) and Seychelles (coded as SE) as well as via Skype interviews (coded as SI). Second, we analyzed 20 fisheries reports from governmental archives regarding the means of access to the fishery, complemented by other reports such as annual reports submitted to the Indian Ocean Tuna Commission (IOTC) by countries, and reports produced by NGOs. Third, we observed fish landings at the main tuna ports of the three countries for both the small-scale, semi-industrial and industrial segments.

\section{Ribot and Peluso's 'theory of access'}

The concept of access, as used here, is broader than often-used concepts of property or legal rights, and permits us to engage with not only regulatory instruments for tuna management, but also social, ecological, and economic contextual factors. By access, we then refer to the use and physical access to the resource as well as to the ability and means to gain benefits from that use. In their theorization of access, Ribot and Peluso (2003) focus on the ability of actors to benefit from resources through the social relationships between people and the webs of power that configure resource access. Their approach consists of distinguishing different types access mechanisms (rights-based and structural) and analyzing them in three steps (left side of Figure 2):

(1) mapping of benefits from a resource,

(2) identifying and situating the mechanisms used by actors to gain, control and maintain access tp these benefits

(3) analyzing the power relations involved in the process.

Ribot and Peluso notably distinguish between gaining, controlling and maintenance of access: gaining access is "the process to establish the access" (p.159); control is "the ability to mediate others' access and the power to direct other's actions" (p.158) and maintenance is "the use of resources and powers to keep access to the resources" (p.159). They identify various mechanisms through which access to resources is gained, controlled and maintained (Table 1).

We will focus on three of Ribot and Peluso's (2003) eight structural and relational mechanisms that influence how actors gain, control, and maintain access to tuna and create power webs where actors at different moments have power (or not) over the resources and the fishery. In the case of the tuna fishery, three mechanisms allow us to uncover particularly well the differentiated access to the resources by actors as they are present in the three segments of the fishery and engender very diverse interactions. These are knowledge, technology, and social relations. We focus particularly on knowledge and technology as they have a key influence on the benefits that could be derived from tuna in terms of catches. Those two mechanisms also have a strong role in the process of co-production of benefits and materiality through their impact on the biophysical aspects of the resources as well as on perceptions around tuna. They also have a direct link with capital, from which the availability of technology and investment in knowledge production around tuna derives. We have chosen the third mechanism, social relations, mainly to bring to the scene the people behind the fishery, whose stories of access to resources are often untold. Through social relations, especially around labor, we are able to explore perspectives on access and resources from the people that are close to those resources and involved at different stages of the commodity chain. It also allowed us to perceive other mechanisms such as social identity or authority. Other access mechanisms, like capital, market, labor and authority in tuna fisheries of the WIO region, have also been explored in other studies (see for example Campling 2012a, 2012b; Havice and Campling 2013, 2017; Lecomte et al. 2017; Wolff et al. 2013). 
The approach outlined by Ribot and Peluso under their theory of access presents three advantages in understanding the dynamics of tuna fishing and management in the WIO. First, the mapping of benefits allows a clear identification of the actors involved. Tuna fisheries are ultimately not only of concern to fishers. They involve multiple actors at different geographical scales who access or control access to the resources and their direct or indirect benefits (Table 1). Second, the approach highlights how gaining, controlling, and maintaining access occurs not just by formal conventions (rights-based access), but many different types of structural and relational mechanisms at multiple scales. Third, through the analysis of power relations, it gives attention to political-economic circumstances that may affect access rights from one group or another.

\section{Materiality and input to the theory of access}

Now we turn to presenting the rationale for enhancing Ribot and Peluso's (2003) theory of access through materiality. Other scholars have attempted to enrich the theory with social concepts (Szaboova et al. 2019, for a recent example), or expand some components of the theory like power or authority (such as Sikor and Lund 2017). Our contribution lies in the integration of materiality. By materiality, we refer not just to the tangible biophysical and spatial characteristics of a resource, but also the ways in which those aspects are constructed through social processes (Bakker and Bridge 2006). This reflects a 'material turn' in political ecology (Bennett 2010; Walker 2005), which explores the active dynamics of non-humans and highlights the importance of biophysical ecology in socio-environmental research. As Robbins puts it, non-human actors "play an important political role in explanation" (Robbins 2003: 643). This leads to a kind of hybrid socionatural materiality that has an impact on access to resources while it is also influenced by this same access. Ribot and Peluso's theory of access (2003) touches indirectly on materiality in mapping access or focusing on technology as a mechanism, but does not explicitly do so, perhaps because the dominant focus was on a shared understanding of land and forest resources. Other studies have emphasized the role of the biophysical characteristics of terrestrial resources in shaping access policies or influencing access negotiations along the commodity chain (Holland and Lansing 2016; Neimark 2010). A recent review of the theory of access has also suggested a better integration of materiality by either considering it as different to access mechanisms or that mechanisms take into account the agency of things (Myers and Hansen 2019).

For mobile resources, their biophysical characteristics and ecological dynamics, often shaped in part by human actions, influence the type of extraction used by commercial and subsistence actors (Sneddon 2007). They can either contribute to the accumulation of capital if extractors have the means to overcome the characteristics that can constitute an obstacle or also be used to claim ownership over a resource for those located nearest to resources (Kaup 2008; Mansfield 2003). Extraction of resources will then take place only where they are present and tangible. Their movement influences the location of their extraction. The case of marine resources, either migratory or fugitive (Giordano 2003), brings questions of biophysicality and spatiality to the fore. Bear (2012) for example discussed the influence of moving marine resources such as bottleneck dolphins in management decisions and how mobility intervenes as a strong force outside the control of human actants. Childs (2018) highlights the use of the fluidity and dynamic qualities of the seabed within deep-sea mining political technologies. Campling and Havice (2014) specifically discuss the role of tuna's characteristics and the spatiality of the sea in shaping the capitalist exploitation of tuna in the WIO. 


\begin{tabular}{|c|c|c|c|}
\hline Category & $\begin{array}{l}\text { Role in access to } \\
\text { resources }\end{array}$ & $\begin{array}{c}\text { In the charcoal commodity } \\
\text { chain (Ribot 1998) }\end{array}$ & In tuna fisheries \\
\hline \multicolumn{4}{|c|}{ Rights-based mechanisms } \\
\hline $\begin{array}{l}\text { Law, } \\
\text { conventions, } \\
\text { permits, } \\
\text { illegal means }\end{array}$ & $\begin{array}{l}\text { Provide right-based access } \\
\text { or illegal access to the } \\
\text { resources }\end{array}$ & $\begin{array}{l}\text { Permits, licenses and quotas to } \\
\text { access the resources and } \\
\text { market. Forest policies to } \\
\text { manage the use of resources, } \\
\text { threat of violence }\end{array}$ & $\begin{array}{l}\text { The international Law of the } \\
\text { sea, permits and licenses, } \\
\text { fisheries' policy, piracy and } \\
\text { illegal fishing }\end{array}$ \\
\hline \multicolumn{4}{|c|}{ Structural and relational mechanism } \\
\hline Technology & $\begin{array}{l}\text { Equipment of all sorts that } \\
\text { improves access or allows } \\
\text { its control }\end{array}$ & $\begin{array}{lll}\text { Technical } & \text { skills } & \text { of } \\
\text { woodcutters } & & \end{array}$ & $\begin{array}{l}\text { Vessels' technology to locate } \\
\text { and catch the fish }\end{array}$ \\
\hline Capital & $\begin{array}{l}\text { Finances that enable } \\
\text { actors to gain and control } \\
\text { access and benefits }\end{array}$ & $\begin{array}{l}\text { Financial capital of wholesaler } \\
\text { in accessing large quantities of } \\
\text { charcoal leading to monopoly }\end{array}$ & $\begin{array}{l}\text { Financial capital by fishing } \\
\text { firms leading to more efficient } \\
\text { vessels with more technology }\end{array}$ \\
\hline Market & $\begin{array}{l}\text { Access to markets } \\
\text { influences who can benefit } \\
\text { from the resources }\end{array}$ & $\begin{array}{l}\text { Control of market access by } \\
\text { merchants through licenses, } \\
\text { permits and social ties with } \\
\text { distributors, retailers and State } \\
\text { agents }\end{array}$ & $\begin{array}{l}\text { Tuna both goes to the } \\
\text { international market, } \\
\text { controlled by DWFNs through } \\
\text { permits and rules of origin, } \\
\text { and to local markets through } \\
\text { fishers and intermediaries }\end{array}$ \\
\hline Labor & $\begin{array}{l}\text { Relations and } \\
\text { opportunities that provide } \\
\text { benefits to those in control } \\
\text { and access to those } \\
\text { without rights }\end{array}$ & $\begin{array}{llr}\text { Labor opportunity } & \text { of } \\
\text { woodcutters } & \text { controlled } & \text { by } \\
\text { merchants } & & \end{array}$ & $\begin{array}{l}\text { Labor opportunities to access } \\
\text { the resources at fishing stage } \\
\text { (controlled by industrial } \\
\text { fishing companies and local } \\
\text { boat owners) and at landing } \\
\text { (controlled by handling and } \\
\text { processing companies) }\end{array}$ \\
\hline Knowledge & $\begin{array}{l}\text { Provides access through } \\
\text { belief systems and by } \\
\text { shaping justifications of } \\
\text { access }\end{array}$ & $\begin{array}{l}\text { Technical knowledge of } \\
\text { woodcutters, knowledge of } \\
\text { price and demand by vendors } \\
\text { to control distribution }\end{array}$ & $\begin{array}{l}\text { Ecological knowledge about } \\
\text { the fish by local fishers, } \\
\text { through technology and } \\
\text { research. Knowledge of } \\
\text { subsidies through social ties } \\
\text { with the State }\end{array}$ \\
\hline Authority & $\begin{array}{l}\text { Allows the control of } \\
\text { access and influences who } \\
\text { benefits }\end{array}$ & $\begin{array}{l}\text { Power of local leaders to } \\
\text { decide forest disposition }\end{array}$ & $\begin{array}{lr}\text { Governments' } & \text { authority in } \\
\text { deciding } & \text { management } \\
\text { measures } & \\
\end{array}$ \\
\hline $\begin{array}{l}\text { Social } \\
\text { identity }\end{array}$ & $\begin{array}{l}\text { Can provide access } \\
\text { through local status or } \\
\text { membership of a group }\end{array}$ & $\begin{array}{l}\text { Ethnic identity to access labor } \\
\text { opportunity }\end{array}$ & $\begin{array}{l}\text { Coastal states nationals to } \\
\text { access labor opportunities on } \\
\text { foreign industrial vessels }\end{array}$ \\
\hline $\begin{array}{l}\text { Other social } \\
\text { relations }\end{array}$ & $\begin{array}{l}\text { Friendship, } \\
\text { reciprocity, patronage, } \\
\text { dependence that can be } \\
\text { used to control and } \\
\text { maintain access to the } \\
\text { resources, markets and } \\
\text { labor opportunities }\end{array}$ & $\begin{array}{l}\text { Social ties between } \\
\text { wholesalers, vendors, the State } \\
\text { and merchants to maintain } \\
\text { access to the market and } \\
\text { control access to distribution }\end{array}$ & $\begin{array}{l}\text { Patronage and trust within } \\
\text { small-scale fishing, patronage } \\
\text { and dependence at the } \\
\text { industrial fishing scale }\end{array}$ \\
\hline
\end{tabular}

Table 1: Categories of right based, structural and relational mechanisms to access resources, from Ribot and Peluso's framework (2003), illustrated for terrestrial resources (Ribot 1998) and tuna resources. (author's analysis) 
Within a theory of access to tuna resources, we argue that materiality is present on three fronts (Figure 2). First, right based mechanisms of access play an important role in the spatialization of the sea, and in the same process aim to establish the right to access tuna resources within geographical boundaries. Second, biophysical attributes of tuna shape and influence structural access mechanisms such as knowledge and technology, which in turn have an impact of the quantity of tuna resources that can be accessed. Third, power relations that intervene between stakeholders can have an influence on the materiality of resources and frame various narratives of overfishing and equitability around the benefits obtained.

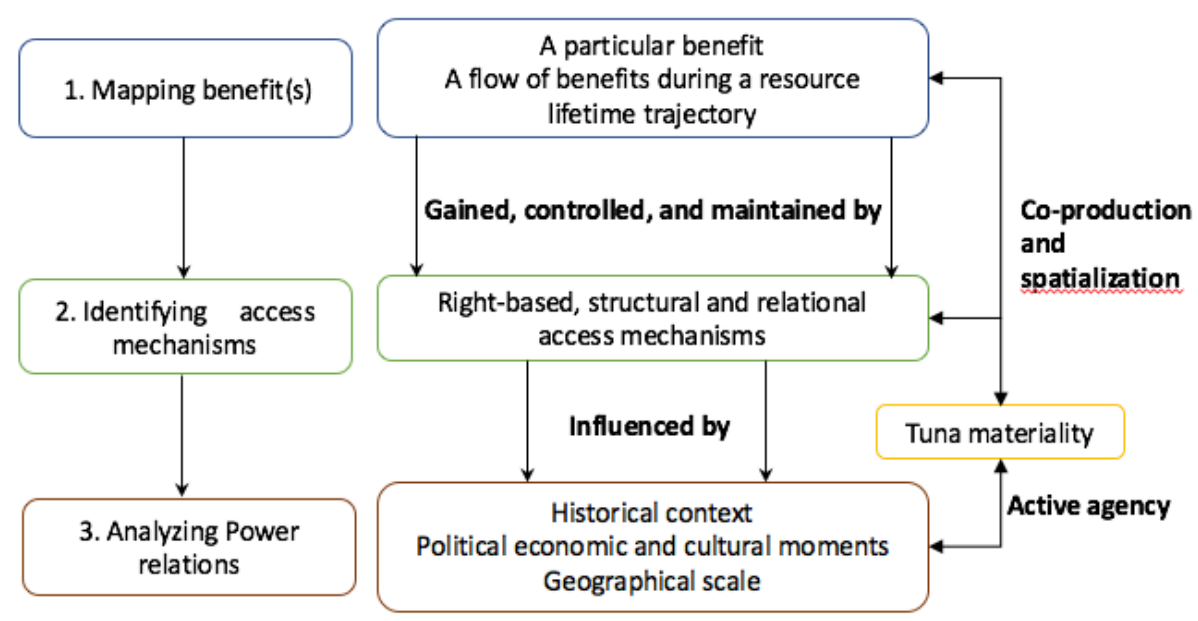

Figure 2: A summary of Ribot and Peluso's mapping of access, enhanced by materiality (2003). Source: authors.

\section{Applying the classic theory of access to tuna resources of the WIO}

We will now illustrate how the theory of access elicits the complexity of tuna fisheries in the WIO. We will first present three rights-based access mechanisms, providing the legal framework of access. Following this, we present three structural mechanisms that are relevant for access to tuna resources. We address refinements for the theory to take account of mobile resources and materiality in a later section.

\section{International rights to the resources: The Law of the Sea and fishing access agreements}

Tuna resources are formally under the control of coastal states when the fish are in the countries' territorial waters or exclusive economic zone (EEZ). These sovereign access rights to marine resources were codified by the United Nations Convention on the Law of the Sea (UNCLOS) in 1982. Outside these zones, in the high seas, no state can claim sovereignty over tuna, which are considered a property of humankind (Figure 3).

In the WIO, countries' EEZs are contiguous in the Mozambique Channel and between the island states of Madagascar, Seychelles, Mauritius and insular territories of France. High seas envelope the WIO to the north, east, and south (Figure 1). This makes the tuna fishery subject to different levels of regulation and control, starting from national property rules (in territorial water), national controls within countries' EEZs, to no control rules in the high seas. The appropriation of tuna resources and the rent they generate under those different rules are highly influenced by the socio-historical context as well as the role of the state in maximizing or mitigating this appropriation (Campling and Havice 2014). 


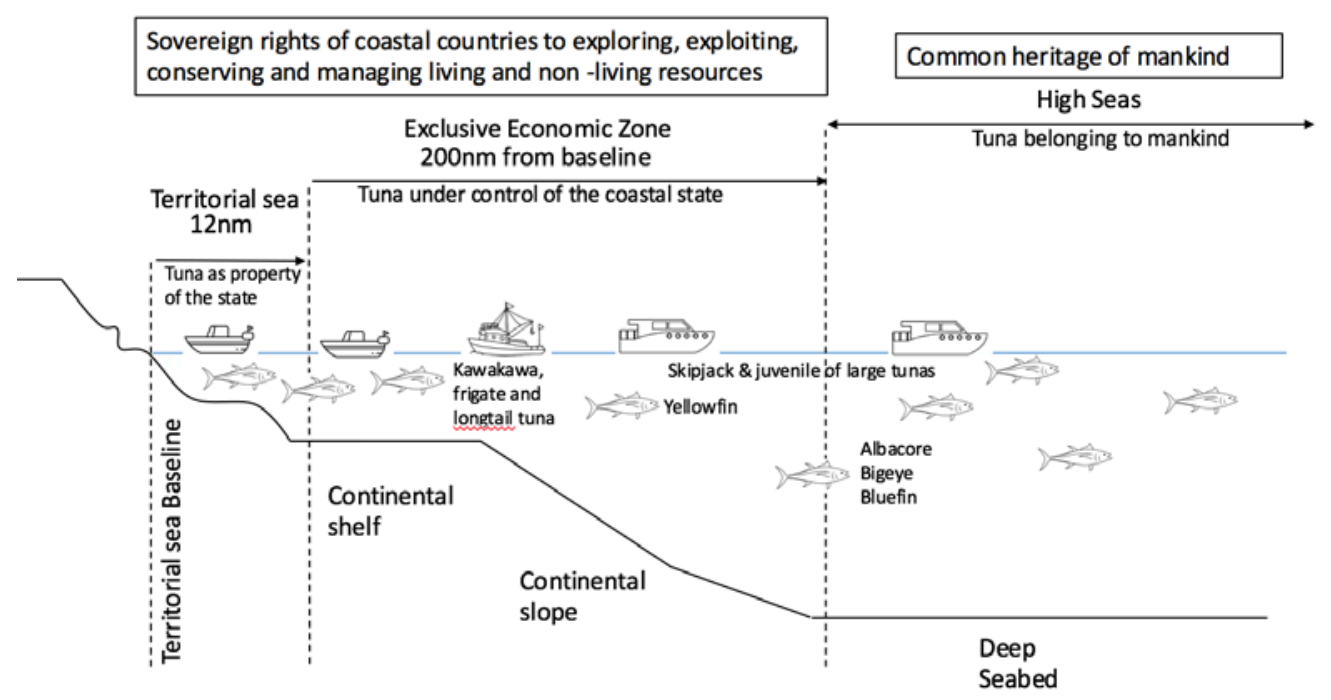

Figure 3: Spatialization of the ocean by the Law of the Seas and rights over tuna in their different location/depths. Source: the authors, adapted from FAO 2000.

Article 62 of the Law of the Sea, stipulates that countries with a limited capacity to harvest their resources shall provide access to the 'surplus' resources to other States (UNCLOS 1982). This provision creates a second type of right-based access mechanism: bilateral fishing access agreements between host countries and distant water fleet nations. In the WIO, the countries involved are mainly Spain, France, Japan, South Korea and Taiwan. The first two typically negotiate fishing access agreements under the flag of the European Union and its program for Sustainable Fisheries Partnership Agreements (SFPA). Fishing access agreements have been criticized for their lack of sustainability, equity and transparency (Gagern and van den Bergh 2013; Le Manach et al. 2013a, 2013b). They also create challenging geo-political negotiations for coastal states, struggles regarding the setting of the appropriate rent, and force states to find a balance between global production demands, national pressure for revenue as well as equity (Barclay and Cartwright 2007; Campling and Havice 2014). This type of access to tuna is therefore linked to highly (geo)political and economic interests, and to unequal negotiations with wealthy countries also highly involved in development aid to the host countries (Barclay and Cartwright 2007; Gegout 2016; Schurman 1998).

\section{National licencing system: control of access within the EEZ}

Other access mechanisms operate at the national level, mainly through various licenses and permits. In the three countries studied, access to resources by national operators depends on the types of activities undertaken and whether they are for the local market or for export. It can range from the issuance of fisher's cards to industrial agreements or export permits (Table 2) (GoMA 2015; GoMU 2007; GoS 2014).

These diverse regulatory and administrative frameworks are, however, not as straightforward as they appear. In addition to challenges of enforcement and monitoring (MD72, government official), there can be conflicts over the fair distribution of licenses, notably between local artisanal fishers and foreign vessels operating under access agreements. In the three countries studied, the activities of foreign boats can be perceived by local fishers as illegal fishing when they are fishing close to the coastline. Fishers made statements such as "there is illegal fishing. We do not know who they are but they come too close to the coast to be legal boats" (MD 06) or "there are big boats that do illegal fishing in our waters, they come close to the coasts at night" (MU 11). This perception of illegal fishing by artisanal fishers exacerbates the issue of fairness of fishing access agreements raised above as it is not seen by some fishing communities as legitimate 
access to resources. This is especially tangible in countries like Mauritius and Seychelles where knowledge about the existence of access agreements is more widespread. Local fishers interviewed in those countries often mention that the state gives too many licenses to big industrial vessels (MU 8, 11, 35, 24; SE 9, 24, 26, 61). Fierce comments such as "we have to reduce the number of tuna purse seiners in our waters as they take all the resources" (SE 9) were commonly heard amongst the semi-industrial fishers in Seychelles. ${ }^{2}$ These conflicting perceptions of legality of access fuel the opposition against industrial fishing, especially purse seiners, in the WIO and make benefits brought by that segment of the fishery less appreciable especially in the opinion of local and semi-industrial fishers.

\begin{tabular}{|c|c|c|c|}
\hline & Madagascar & Mauritius & Seychelles \\
\hline Artisanal/subsistence & Fisher's card & \multicolumn{2}{|c|}{$\begin{array}{l}\text { Fisher's card } \\
\text { Boat license }\end{array}$} \\
\hline Local semi-industrial & $\begin{array}{l}\text { Fishing access agreement } \\
\text { Boat license }\end{array}$ & \multicolumn{2}{|c|}{$\begin{array}{c}\text { Fishing permit } \\
\text { Boat license }\end{array}$} \\
\hline Selling to local markets & \multicolumn{3}{|c|}{$\begin{array}{l}\text { Selling permit for fishers } \\
\text { Collection and selling permit for intermediaries }\end{array}$} \\
\hline Exporting & \multicolumn{3}{|c|}{ Export permit (issued to fishers or processing companies) } \\
\hline
\end{tabular}

Table 2: Different types of permits to access the fishery and sell the catch.

\section{Conservation measures regulating access to fishing grounds}

Other forms of regulations beyond licensing also shape access to marine resources. These can include no-take zones from marine protected areas, fisheries closures, prohibition of some types of gear or local conventions between community members (Bennett and Dearden 2014; Kincaid et al. 2014; Walker and Robinson 2009). We do not elaborate on these here; however, we will briefly mention how tuna fits within these forms of regulation.

In the three countries studied, tuna is not subject to any closure periods, the reasons being that most tuna are caught further from the coast and their movement combined with seasonality make it difficult to establish a closure. Tuna species travel in schools that may be a mix of different species and include both juvenile and catchable fish. Setting up closures would require a precise knowledge of the movement patterns and species constitution of the various schools of tuna present in the WIO. Enforcement would require substantial investment in control and surveillance for coastal states. More sedentary tuna (such as bonitos) are present close to the coast and could be present in marine protected areas, hence access is limited. In Madagascar and Mauritius, fishers did not mention marine protected areas as a major obstacle to their fishing because their fishing grounds were not close to MPAs (MD 51, MU 18, local fishers). In the Seychelles, however, news about an upcoming large new MPA raised concerns amongst fishers as a threat to access to tuna grounds (SE 29, 47, 48, local fishers) while the government positions itself as a lead player in the blue economy through this initiative (Schutter and Hicks 2019). Madagascar has developed many local conventions in managing its marine resources. However, while it has restrictions on species such as octopus, crabs and sea cucumbers, these restrictions do not address big pelagic species like tuna (MD 80, 81, government official and NGO representative). In the broader Indian Ocean region, however, yellowfin tuna species are considered overfished and currently under a rebuilding plan (IOTC 2015). The latter involves the reduction of catch by different fishing methods, from 5\% to 15\% from fleets' 2014 or 2015 catch levels (IOTC 2016).

${ }^{2}$ Similar comments were made by SE 24, 26 and 61. 
Looking at rights-based mechanisms of access to tuna resources highlights the multi-layered facets of managing an international and mobile resource. In the current context of the blue economy where marine assets such as seabed resources or oil and gases are seen as holding important potential, African countries need to be aware of the legal framework and rights associated with such resources, especially in regards to access by foreign countries and entities. We will now show that tuna fisheries are shaped by more than the legal frameworks under which they are regulated.

\section{Knowledge as key to locate the tuna and access the fishery}

Ribot and Peluso (2003) see 'knowledge' as a category of access mechanism. This mechanism includes not only the direct influence of knowledge (e.g. fishing expertise) on who can benefit from resources, but also the role of control over information and knowledge in shaping access. The knowledge held by fishers has been recognized as contributing to a better management of fisheries through their contribution to local rules and institutions and by providing key information regarding the socio-ecological state of marine resources and ecosystems (Robinson et al. 2014; St Martin 2007). This knowledge plays an important role in how fishers perceive resources and the benefits provided, as well how they prioritize one type of management or another (Daw 2008; Hicks and Cinner 2014). For the case of tuna, two types of knowledge are key. First, there is the knowledge about the tuna itself. This includes knowledge about where which species of tuna is found at what period of the year. Second is the knowledge about the means to access the fishery. This includes knowledge about the licensing system or about accessing subsidies for equipment, fuel or upgrading of boats. This knowledge is generated differently by participants in the artisanal and industrial fisheries and is key in determining the amount of tuna that can be fished.

For artisanal and semi-industrial fishers, knowledge about tuna is gained through long individual experience, often over a period of five to twenty years as well as from information transferred among generations regarding the seasons, the warmth of water preferred by tuna, the area and distance where the tuna can be found. Amongst the 75 small-scale and semi-industrial fishers interviewed, 53 were able to provide knowledge about the location of the fish, seasonality or specific features and catchability of tuna in the EEZs.

Knowledge is not limited to so-called 'locals.' In the Seychelles, the semi-industrial fishing fleet is crewed mainly by Sri Lankans. Here, knowledge regarding tuna fishing is mainly produced by the Sri Lankan crew. Some boat owners (often former artisanal Seychellois fishers) consider the Sri Lankans as better seafarers for tuna and talk of their Sri Lankan crew members as having a more advanced knowledge on where and how to fish tuna compared to the Seychellois (SE 21, 42, 45, 61). They make statements such as "they look at the moon and know where the fish is going" (SE 42) or "they - the Sri Lankans - have fished tuna for many years in their country, their fishing technique is better, the catch is better with them fishing" (SE 45).

The transmission of knowledge is not just through experience and between individuals, but also through, for instance, fisher associations. These fora allow fishers to share their knowledge on fishing techniques and state of the resources or obtain knowledge on the latest developments in the fishery, like new legislation, licensing processes or potential subsidies (Belahy 2017, MU 24, SE 29, SE 47, local fishers).

In the industrial sector, knowledge about tuna's location and their biological characteristics is produced through numerous channels. There is first the experience of fishers. In the WIO region for example some Spanish captains of European purse seiners have been fishing in the region between five to ten years (MD 44, 45), accumulating knowledge about the migration pattern of tuna in the region. For foreign fleets operating in the region, technology also plays a key role in the production of knowledge regarding tuna. Vessels are equipped with various radars and screens that indicate where the fish are located from buoys and fish aggregating devices that have been placed during previous fishing trips. European fleets in the WIO also have access to their home countries' research institutes that are dedicated to producing knowledge regarding tuna based on catch data, observers on board and specific research activities on tuna behaviors. These research institutes - specifically the French Institut de recherche pour le développement (IRD) and the Spanish Instituto Español de Oceanografía (IEO) - both have offices focused on tuna fisheries in the Seychelles. The 
knowledge produced is then shared with fleets and managers of the fisheries, via the ship-owner associations or the country representatives negotiating at the regional management meetings of the Indian Ocean Tuna Commission (IOTC).

This availability of knowledge to the foreign fleet raises the issue of equity with the artisanal fishery and national fleets. Fishing associations of artisanal fishers claim that industrial boats know exactly where the fish are and their quantity before they even leave the port. Members of a fishing association vigorously argued that "there is a substantive problem regarding access to the tuna as the purse seiners, before leaving the port, already appropriate the fish" (SE 29) or that "research on tuna is mostly funded by the industry, means that are not available to local fishers" (SE 47). This situation is perceived as an unbalanced access to knowledge that leads to unequal access to tuna resources.

Looking at knowledge using the framework of Ribot and Peluso allowed us to map the different actors that produce the knowledge needed to access tuna and its fishing. We also highlight the importance of control over knowledge not only in accessing more resources but also in shaping more general knowledge about the state of resources and in generating narratives of unequal access to them, often carried by the artisanal fishery. This control over knowledge will be an important issue for other activities of the blue economy in Africa, where local knowledge on the use of marine resources is only starting to be recognized and where there is currently limited production of knowledge regarding other marine assets.

\section{Technology as a determinant of tuna catch levels}

Technology, in Ribot and Peluso's (2003) framework, is a mechanism that can be used to improve access or restrict others' access. In terms of tuna fishing, we have seen above that technology plays an important role in the production of knowledge that in turn facilitates access. But technology also plays a direct role in getting to fishing grounds, catching fish, storing fish, and transporting them in larger quantities. The evolution of technology after World War II has been well documented as the main factor of a drastic increase in catch and an improvement of efficiency in fishing techniques (Pauly and Le Manach 2012; Sumaila et al. 2016). Technology has brought more powerful vessels, a diversification of fishing strategies and especially highly efficient fish detection devices (Torres-Irineo et al. 2014). Technology as a mechanism of access to the resource is therefore a central component for tuna fisheries in the WIO. Availability of technology is mainly driven by operators' capacity to access capital but also the socio-economic contexts within which they operate. Similar to the availability of knowledge, technology available in the two segments of the fishery varies considerably and impacts the quantity of fish that can be caught.

The role of technology in shaping access is important because extraction rates depend on the technology that is used. Table 3 summarizes the types of technology utilized by fishers in each of the segment of the fishery. The disparities between the three sectors are immense and the catch of the industrial sector much higher than the two other sectors.

In tuna fisheries, in addition to operators' ability to invest in technologies, the state also plays an important role in bringing capital in to provide technologies in the two segments of the fishery. In Madagascar, the small-scale fishers often have very limited technology available and can catch a limited amount of tuna. In Mauritius and Seychelles, provided their more favorable socio-economic contexts, artisanal fishers, in additional to their own capital and investments, receive assistance in the form of loans to buy boats and improve their fishing gears, or they have fish aggregating devices installed by the fisheries departments to increase their productivity (see section 6). Here being registered as a fisher through licenses is the key condition to access financial support such as free interest loans to buy gear and boats. 


\begin{tabular}{|c|c|c|c|c|}
\hline $\begin{array}{l}\text { Segment and } \\
\text { Technique }\end{array}$ & Boats & Equipment & \multicolumn{2}{|c|}{$\begin{array}{l}\text { Estimated catch in the WIO } \\
\text { and source }\end{array}$} \\
\hline $\begin{array}{l}\text { Artisanal } \\
\text { handline and } \\
\text { trolling }\end{array}$ & $\begin{array}{l}2 \mathrm{~m} \text { to } 12 \mathrm{~m} \text { boats } \\
\text { (wooden or fiber } \\
\text { glass) }\end{array}$ & $\begin{array}{l}\text { - GPS devices } \\
\text { - } 2 \text { to } 5 \text { lines with hooks } \\
\text { - Fish Aggregating } \\
\text { Devices (in Mauritius) }\end{array}$ & $\begin{array}{l}\text { 50mt/year } \\
\text { (Seychelles) }\end{array}$ & SFA 2016 \\
\hline $\begin{array}{l}\text { Semi-industrial } \\
\text { Longline }\end{array}$ & $\begin{array}{l}12 \mathrm{~m} \text { to } 34 \mathrm{~m} \\
\text { boats }\end{array}$ & $\begin{array}{l}\text { - GPS devices } \\
\text { - Lines (of } 20 \text { to } \\
100 \mathrm{~km} \text { ) and hooks } \\
\text { - Long view binoculars }\end{array}$ & $\begin{array}{l}\text { Up to } 500 \mathrm{mt} / \text { year } \\
\text { (Madagascar) } \\
\text { Up to 200mt/year } \\
\text { (Mauritius) } \\
\text { Up to 970mt/year } \\
\text { (Seychelles) }\end{array}$ & $\begin{array}{l}\text { Razafimandimby } \\
\text { and Joachim } \\
\text { 2016; } \\
\text { Mootoosamy et } \\
\text { al. 2017; } \\
\text { Assan } \text { et al. } 2017\end{array}$ \\
\hline $\begin{array}{l}\text { Industrial } \\
\text { Longline and } \\
\text { purse seine }\end{array}$ & $\begin{array}{l}\text { - } 40 \mathrm{~m} \text { to } 60 \mathrm{~m} \\
\text { longliners } \\
\text { - } 80 \mathrm{~m} \text { to } 110 \mathrm{~m} \\
\text { purse seiners }\end{array}$ & $\begin{array}{l}\text { - Lines (of } 20 \text { to } \\
100 \mathrm{~km}) \text { and hooks } \\
\text { - Nets (1500m to } \\
2000 \mathrm{~m}) \\
\text { - Fish Aggregating } \\
\text { Devices (FADs) } \\
\text { - Sonars } \\
\text { - Support vessels }{ }^{3}\end{array}$ & 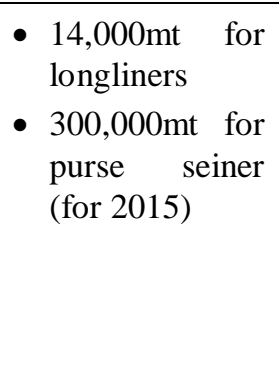 & SFA 2016 \\
\hline
\end{tabular}

Table 3: Types of technologies used in the three segments of the fishery and their recorded catches.

In the semi-industrial sector, access to improved technology has been a key policy. In Mauritius, a campaign in 2017 was launched by the Fisheries Department to help fishers buy semi-industrial boats in the form of loan by the Mauritian Bank and a grant by the State of up to US $\$ 100,000$ (4 million Rp), with the condition that fishers be part of an officially registered fishing cooperative. Five cooperatives out of eleven received this financial support in 2017 (GoMU 2017). In Seychelles, loans to purchase semi-industrial boats have been encouraged over the past 5 years. The number of semi-industrial boats have increased from 4 in 2006 to 29 in 2016 (Assan et al. 2017; SFA 2010). Financial solvency of the investors was the main criteria of accessing those loans (SE 60).

In the industrial fishery and especially for foreign fleets, investment in technology is high and state subsidies are available to ship owners. A global study of subsidies estimates that around US\$20 billion have been invested in 2009 by developed country governments in capacity-enhancing subsidies with around US $\$ 5$ billion for the EU and US\$3.5 billion for Japan (Sumaila et al. 2016a). Those include subsidies for boat construction, renewal and modernization programs or tax exemption through fuel subsidies.

The divide between the different segments of the fishery created by technology is clear. The domination of the industrial sector in the fishery is apparent. This is perceived by host countries and their local fishers as one of the main contributors to the overfishing of tuna resources in the region. Phrases like "there are too many boats and FADs in the sea" (MU 33, SE 19) were commonly heard from both fishers and processing companies.

Exploring the role of technology through the framework of Ribot and Peluso shows that technology is the mechanism of access that allows the industrial segment to benefit the most from the fishery. Technology

${ }^{3}$ Vessels that help to locate the tuna and supply fuel to the tuna vessel. 
in tuna fisheries enhances access to resources in terms of their physical distance, but also in the tangible quantity of resources gained. We also showed that the state, which can contribute to providing access to these technologies, plays an important role in providing capital to facilitate this access to the different segments of the fishery, and also in assisting the industrial sector in maintaining the same type of sophisticated access through provision of subsidies. In the context of a sustainable Blue Economy, the involvement of the state in providing capital and access to technology requires holistic thinking, especially on the level of investments made and the actual ecological impacts of such investment on ocean resources. As tuna fisheries show, investment in technology has been substantial without enough consideration of either ecological sustainability nor equity between local and industrial sectors.

\section{Relations that provide access for hidden actors}

The two previous sub-sections showed that accessing tuna requires different types of knowledge but also technologies. Here we will show that gaining, controlling, and maintaining access to particular parts of the tuna commodity chain is also very much about who you know, and how you interact with the actors in the tuna fishing arena. This is the central element of Ribot and Peluso's (2003) 'social relations' mechanism of access. Fishing in general and tuna fishing in particular is a social activity, in the sense that it involves diverse social relations of production, can encompass the creation of social networks, often requires effective communication between fishers, and can create connections or social conflicts between the different segment of a fishery (Barclay 2010; Barnes et al. 2016; Voyer et al. 2017). As presented in Ribot and Peluso's theory of access (2003), social relations can include complex relations of friendship, trust, patronage, reciprocity and dependence. In the WIO tuna fisheries, in each segment of the fishery and up and down the value chain, these relations determine who controls labor opportunities and improve or limit actors' access to tuna markets. We give two examples of relations that allow locals of host countries to access tuna fished by the EU-run industrial sector. Those relations take place at two stages of the commodity chain, at production when fish are caught, and at processing, when they are landed for canneries. We found that at those two stages, some local actors play a non-negligible part in resource access, without much recognition in other studies of tuna fisheries.

First, patronage relationships exist between locals of the WIO and EU fishing firms. In the industrial fishery run by EU companies, Fishing Access Agreements establish labor opportunities for nationals of host countries. The crews of industrial boats are comprised of a majority of Europeans as well as nationals from developing countries. A typical purse seiner fishing in the WIO region would include Spanish or French together with Senegalese, Ghanaian, Ivorian, Seychellois or Malagasy crew members. This diversity of the crew is legislated by the Fishing Access Agreements within which a percentage of the crew must come from African, Caribbean and Pacific (ACP) countries including the host countries where the fishing takes place (Goulding 2016; Macfadyen 2015). In the Indian Ocean, an average of 700 ACP nationals are annually employed by the EU tuna fleet (Macfadyen 2015, annexes), of which around 200 are operating in the WIO (POSEIDON et al. 2014).

Those non-EU crew members have resource access through their jobs, depending on fishing companies for contracts and gaining a financial benefit through wages rather than fish. When those working on EU vessels for more than five years were asked about their compensation, many of them responded that they were satisfied by the wages and work conditions they had, against what they can make in their home countries but not compared with the profits of the fishing companies (MD 42, 46, 87 - Malagasy, Senegalese and Ghanaian crew members on Spanish vessels). Sentences like "I make a good living compared to what I can earn at home" were common amongst the non-EU crew along with "In the end it's the big bosses sitting in Madrid that make the money, we are only fishers, we do not gain much." They were often performing nonspecialized roles on tuna vessels. Therefore, despite the labor opportunity they get, their wages are much lower than EU nationals on board, estimated at around 7 times less (Campling 2012b). Similarly, while wages are usually considered a substantial operational cost for EU vessels (amounting around 30\%), the EU fleet in the Indian Ocean, including in the WIO has been evaluated as highly profitable, generating more than US\$100 million in gross profit for 2016 (Carvalho et al. 2018). Non-EU crew members play an important role 
and help to generate these profits, gaining more revenue than other home-based fishers and yet less than EU crew members.

Secondly, another labor opportunity that foreign fleets provide is stevedoring at the port. In Madagascar, landing boats employ local stevedores to unload the fish to the canneries. In this process, nontuna species, and damaged or undersized tuna are given or sold to them at US\$0.1/kg, on top of their wage (USTA 2017). With an average landing of 480t/year, these fishes are then sold at the port by stevedores every evening of landings at US\$1 to US\$1.5/kg (USTA 2017). The socio-economic context in Madagascar means wages for these positions are not very high (less than \$US2/hour according to MD 04, government official), so the 'real wage' includes the sale of fish they are offered. The importance of these local market events has made access to these jobs a very competitive business, requiring stevedores to build personal and economic ties with those holding authority at the handling companies, including through financial gifts (MD 04, 36, government officials). This supply of fish is seen by some as unwanted competition to local tuna fishers (SI 01, NGO representative), and by others as a welcome source of cheap fish in a city with a high cost of living (MD 05, 39, local residents of Antsiranana). One resident emphasized that "the coming of tuna from the big boats periodically regulates the price of all goods in Antsiranana. Without this tuna, everything remains at high price the whole year" (MD 05). Local fishers, asked about this competition, acknowledged a decrease in price of locally caught tuna when the industrial ones are landed. However, they considered this was manageable as they could still sell their fish, and the competition was only a couple of months a year (MD 24, 26, local tuna fishers). The stevedores are, in the North of Madagascar, an important but easily neglected part of the tuna fishery scene, supplying the local market. They also change the perception on the industrial 'unwanted' tuna to an economically local 'needed' fish. Labor, and reciprocity through diverse social relations, are a key mechanism for different actors to gain access to the tuna value chain at sea or at port.

We have highlighted the diverse and often unseen actors in the fishery, and the social and labor relations that allow them to access and obtain benefits. As provision of jobs constitutes one of the pillars of building Africa's blue economy, less visible opportunities need to be accounted for appropriately. As seen in tuna and fisheries in general, the indirect value of fisheries is still vastly underestimated, at least in the WIO (Obura et al. 2017). This is important for new ocean related projects that aim to improve labor opportunities for African populations.

\section{A materiality-infused theory of access}

We will now illustrate the role of materiality in access to tuna resources. We will do so with two examples. One highlights the influence of the geographical configuration of the sea and the migration of tuna for resource access. The second will show how technology and practices produce a new materiality of tuna. We will end the section by presenting the mapping of access to tuna resources in the WIO under our materiality-infused theory of access.

\section{Spatiality and movement}

Tuna fishing takes place in waters that are ecologically distinct (from near coastal reefs to deep water), carved into particular geo-political and economic territories, through which the different species move and circulate. Tuna move within high seas, with an open access regime, and also within the legally defined space of EEZs between countries of the WIO region. Tuna become the property of different nations when they pass into their EEZs, and in effect become fugitive resources as soon as they move and are caught in another EEZ (Giordano 2003). This pushes host countries to profit from them before they move on. One government official commented "the resources move beyond our waters, if they are not fished in our waters, they will be fished elsewhere, it will be a loss for us" (MD 02). This situation is different when fish reach the high seas. As there are no access rules or property regime applicable here, fishing vessels are free to catch tuna without any specific regulation. However, they are constrained, when full, by their need to land and transship at the closest ports, which in the WIO are in Victoria, Antsiranana, Port Louis and Mombasa, far from the high seas (MU 30, government official; MD 42 and SE 66, industrial fishers). Catching fish in the high seas still requires going back to ports in order to respond to canneries' demands. Industrial fishers interviewed that were landing 
in Madagascar for example made statements such as "if we fish in the Mozambique channel, we land in Madagascar because it is closer and we can go back fast at sea, it gives us more time to fish" (MD 42) or "we fish in the EEZs and in the high seas, we land and transship where it is the closest for us, it could be in Madagascar, Seychelles or Mauritius" (MD 45).

The imagined political boundaries of the sea are, however, not respected by mobile tuna. Skipjack for example are found in the waters of Madagascar and Seychelles between March and June, gather in the waters of Seychelles between June and October then travel to the waters of Madagascar between November and February. Other species can be found all year long in different countries' waters or undertake circular migration. Yellowfin and bigeye tuna for example are found in the coastal waters of Madagascar, Mauritius and Seychelles between April and December and further offshore between November and March. Coastal tuna are also present all year in the coastal waters (Davies et al. 2014; Fonteneau 2014; analysis of authors).

Tuna has a hybrid spatiality, in which fish migration traverses geopolitical boundaries. This makes access mechanisms highly diverse in terms of the actors and content. Here, tuna is an agent that deterritorializes established legal access boundaries. It forces foreign fishing vessels to negotiate access with different host countries of the WIO to catch the same school of tuna. It also gives power over controls on access to the coastal states in the EEZs, but only until fish move to the high seas.

\section{Co-produced tuna spatiality}

Tuna are undisciplined and mobile, and can be a productive resource one year and not in another. Their materiality is produced by fishing practices. That can be illustrated by two cases in the WIO region: the use of Fish Aggregating Devices (FADs) and piracy.

In the Indian Ocean, 30 to 50\% of purse seine catches are made using FADs (Dagorn et al. 2013; Kaplan et al. 2014). FADs are manufactured floating objects that attract fish. They can be anchored (consisting of a float, mooring line, anchor and some type of underwater structure/attractant) or drifting (made of a floating structure such as a bamboo raft or using naturally occurring floating objects such as logs). They are accompanied by locating buoys and sometimes an echo sounder that can predict biomass (Dagorn 2012; Pew 2011). The use of FADs has been adopted as a fishing practice from an understanding that fish are naturally attracted by floating objects for protection against predation, for food, association or protection of eggs and larvae (Castro 2002; Dagorn 2012). FADs are used in the industrial and in the artisanal sectors. In tuna fisheries they are mainly used by the purse seine industry. It is estimated that around 7,000 units were deployed by purse seiners in the Indian Ocean in 2010, rising to 14,000 in 2013 (Pew 2015).

While they increase productivity and facilitate the localization of the fish, their impact on the ecological behavior of the fish is debated. There may be higher risks of overfishing for some species such as skipjack, because of the aggregation of juveniles under FADs or the disruption of the fishes' natural search for food, hence altering migration patterns (Davies et al. 2014; Pew 2015). Tuna could be attracted to FADs in areas of otherwise poor conditions, changing their natural movements as well as impacting their growth (Dagorn 2012; Davies et al. 2014). The use of FADs has therefore produced another type of tuna materiality, changing migratory behavior and even biophysical traits. Interactions between fishers and tuna through FADs co-produce materiality that increase the catch, reduce the extent of tuna agency, and modify fish traits.

Another practice that had an impact on the materiality of tuna in the WIO is Somalian piracy. Between 2005 and 2009, piracy was rife in the Indian Ocean, preventing many industrial vessels from fishing safely (Chassot et al. 2010). IOTC Reports note that the tuna catch shrunk in the region during the piracy period and that Somalian piracy could have been one of the causes of this decrease in catch and reduction of active vessels (e.g. IOTC 2012: 38; IOTC 2014: 38).

Since 2011, however, the production of tuna has steadily increased in the region (IOTC 2016a). Between 2010 and 2016, the number of purse seiners operating in the WIO increased by 53\%. In addition, the number of supply vessels that help locate the tuna increased from 7 in 2010 to 26 in 2016 (MU 33, processing company representative). Interviewees confirmed this anecdotally, for instance: "there is a lot of fish in the canal this year, because of the pirates, the resources could rest and rebound" (MD 42, industrial fisher) or "the piracy had a major impact in reducing the numbers of boat coming in the WIO region" (SE 31, government 
official) and "the piracy events between 2008 and 2012 almost closed the fishing which relieved the pressure on the resources" (SI 02, government official). The health of the tuna stock can then be influenced by sociopolitical practices such as piracy taking place far from the national waters. The frantic race to fish since controls on piracy were implemented since 2009 could be one reason why the yellowfin tuna stock collapsed in 2015 (SI 02).

Those two examples illustrate how intrinsic and co-produced materiality can shape the benefits from the fishery, notably the quantity of tuna resources. In any Blue Economy initiative, the role of non-humans will be a key aspect, be it the seabed, the characteristics of oil and gas, or the movement of species between territorial boundaries. As we have demonstrated here for tuna fisheries, involvement with the ocean and its resources without much attention to its materiality can result in unexpected (and more likely, negative) impacts on resources and the marine ecosystem.

Looking back at the theory of access and the importance of material conditions, we argue that materiality requires more attention, particularly for mobile resources, migratory species, and the marine space. We suggest enhancing Ribot and Peluso's theory (2003) by making the role of materiality and its hybrid origins more obvious when mapping access. This could be done at all three stages: linking materiality to benefits received, considering the role of access mechanisms in producing materiality (through coproduction), and examining how biophysical and socially constructed materiality shape power relations (Figure 4).

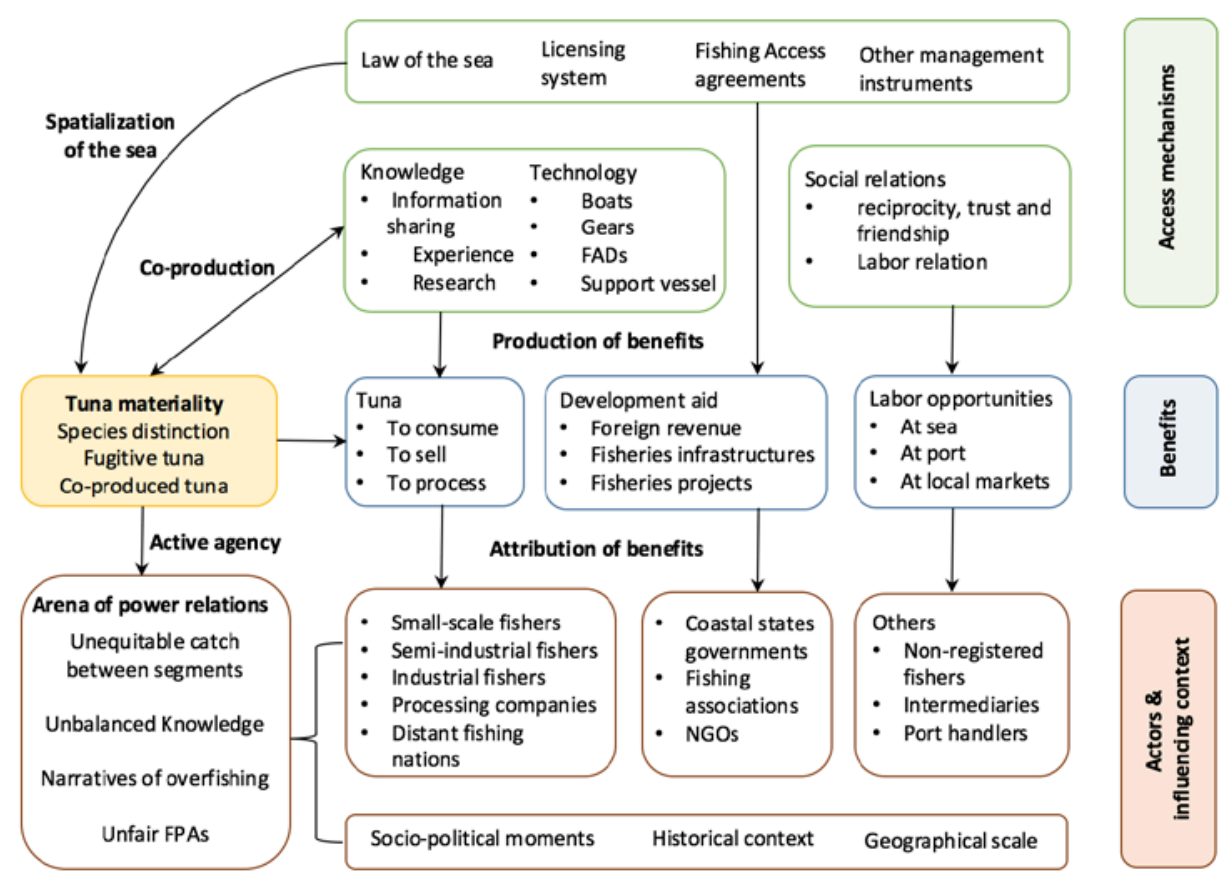

Figure 4: A mapping of access to tuna fisheries in the WIO, integrating materiality.

\section{Discussion and conclusion}

Using Ribot and Peluso's theory of access (2003) to explore tuna fisheries in the WIO gave us a deeper understanding of the array of actors behind the fishery, their interactions, and the different power relations that form through the different mechanisms of access to tuna. Exposing right-based access mechanisms showed that beyond direct revenues from the fishery, a range of indirect actors from intermediaries to port workers and coastal community members also benefit. Rights-based mechanisms are also a source of geopolitical interactions between countries that can influence aid and development trajectories. Analysis of structural and relational mechanisms showed that access to the benefits of tuna fishing is shaped by composite 
knowledge, advanced technology and a multiplicity of social relations, generating power relations that are not fixed or permanent. Actors, through various mechanisms, depending on the socio-political contexts and the interactions, have power over the resources at specific temporal and spatial scales. Countries and their fishers benefit from labor opportunities and development aid that the fisheries bring, as well as their contribution to food security. However, in the broader picture, the distant fishing nations and especially their powerful fishing firms are the ones who accumulate the majority of the benefits by harvesting large amounts of tuna. Our study is a 'reality check' on how ocean-related activities create situated winners and losers from the current way of extracting marine resources. Other Blue Economy activities will face even greater challenges if African countries rely on the same model of resources use, mainly dependent on foreign actors for exploitation and with limited knowledge production.

Looking back at Ribot and Peluso's theory of access, we can also say that for mobile resources and especially tuna, materiality plays a substantial role in the co-production of benefits and mechanisms of access. It infuses the different steps of the mapping of access and gives tuna an active role in determining how the fishery takes place across the various spatial boundaries of the Western Indian Ocean (Figure 4). Ignoring the biophysical specificities of tuna contributes to contestations between fishing actors who may not always be talking about the same species. The movement of fish across various jurisdictions requires actors to negotiate and control access to them, but that control is lost in the high seas. It has also prompted access by more powerful actors through advanced technology. In the current Blue Economy framework, measures addressing sustainability of tuna as a resource must control access in the EEZs but also in the high seas that are currently in an open-access regime. Materiality can constitute and mediate power relations, making different actors small scale/industrial fishers or host countries/distant fishing nations, at different spatial scales - competitors, negotiators or protestors over resource access.

It is also evident from this case that using the theory of access can be difficult in a multi-scaled study. One of the challenges is in introducing the role of geopolitics in shaping access and influencing mechanisms of access. To use the theory requires a careful attention to the question of scale. However, it offers several clarifications to often-overlooked aspects of tuna fisheries and could be helpful in making discussions of access to similar types of resources more mindful of the entanglement between human and non-human actors, and the heterogeneity of means of access involved.

Despite the potential that other Blue Economy activities present in and around Africa, tuna remains essential to the economies of the island nations of the WIO, especially in vulnerable countries like Madagascar where there are few alternative revenue sources. Questions of access to tuna are important in building the blue economy of those countries. If the goal is to attain economic development and sustainability, the interests of all parties should be taken into consideration, including those of the tuna species in the WIO region. Management of tuna needs to be a co-production by humans and non-humans that considers the spatial implications of their mobility, and the situated relations of power that take place at different geographical scales.

\section{References}

Assan, C., J. Lucas, and V. Lucas. 2017. Seychelles National Report to the Scientific Committee of the Indian Ocean Tuna Commission. IOTC-2017-SC20-NR22.

Bakker, K. and G. Bridge. 2006. Material worlds? Resource geographies and the 'matter of nature'. Progress in Human Geography 30: 5-27.

Barclay, K. and I. Cartwright. 2007. Governance of tuna industries: The key to economic viability and sustainability in the Western and Central Pacific Ocean. Marine Policy 31(3): 348-358.

Barclay, K. 2010. Impacts of tuna industries on coastal communities in Pacific Island countries. Marine Policy 34(3): 406-413.

Barnes, M. L., J. Lynham, K. Kalberg and P. Leung 2016. Social networks and environmental outcomes. Proceedings of the National Academy of Sciences 113(23): 6466-6471. 
Bear, C. 2013. Assembling the sea: materiality, movement and regulatory practices in the Cardigan Bay scallop fishery. Cultural Geographies 20(1): 21-41.

Belalahy, J. 2017. Association Tazara-Toamasina: de nouvelles installations inaugurées Jeudi dernier. Newspaper article. Midi Madagascar February $13^{\text {th }} 2017$.

Bennett, J. 2010. Vibrant matter: a political ecology of things. Durham, NC: Duke University Press.

Bennett, N.J. and P. Dearden. 2014. Why local people do not support conservation: community perceptions of marine protected area livelihood impacts, governance and management in Thailand. Marine Policy 44: 107-116.

Breuil, C. and D. Grima. 2014. Baseline report Madagascar. Ebene, Mauritius: SmartFish Programme of the Indian Ocean SmartFish Programme of the Indian Ocean Commission, Fisheries Management FAO component.

Campling, L. 2012a. The tuna 'commodity frontier'- business strategies and environment in the industrial tuna fisheries of the Western Indian Ocean. Journal of Agrarian Change 12(2): 252-278.

Campling, L. 2012b. The EU-centered commodity chain in canned tuna and upgrading in Seychelles. PhD dissertation. SOAS, University of London.

Campling, L. and E. Havice. 2014. The problem of property in industrial fisheries. Journal of Peasant Studies 41(5): 707-727.

Castro, J., J.A. Santiag and A.T. Santana-Ortega. 2002. A general theory on fish aggregation to floating objects: an alternative to the meeting point hypothesis. Reviews in Fish Biology and Fisheries 11: 255277.

Chassot, E., P. Dewals, L. Floch, V. Lucas, M. Morales-Vargas and D. Kaplan. 2010. Analysis of the effects of Somali piracy on the European tuna purse seine fisheries of the Indian Ocean. IOTC Scientific Document IOTC-2010-SC-09.

Childs, J. 2018. Extraction in four dimensions: time, space and the emerging geo(-)politics of deep-sea mining. Geopolitics in press.

Childs, J. and C.C. Hicks. 2019. Securing the blue: political ecologies of the blue economy in Africa. Journal of Political Ecology 26: 323-340.

COFREPECHE, NFDS, MRAG and POSEIDON. 2016. Ex post and ex ante evaluation of the protocol to the Fisheries Partnership Agreement between the EU and the Republic of Mauritius. Framework contract MARE/2011/01 - Lot 3, specific contract 16. Brussels.

Collette, B., et al. 2011. The IUCN Red List of Threatened Species 2011. Version 2015.2. Downloaded on 7 February 2015.

Dagorn, L. 1994. Le comportement des thons tropicaux modélisé selon les principes de la vie artificielle. $\mathrm{PhD}$ dissertation. ENSA de Rennes. Travaux et Documents Microédités, 133. Paris: ORSTOM.

Dagorn, L., K.N. Holland, V. Restrepo and G. Moreno. 2012. Is it good or bad to fish with FADs? What are the real impacts of the use of drifting FADs on pelagic marine ecosystems? Fish and Fisheries 14(3): 391-415.

Davies T.K., C.C. Mees and E.J. Milner-Gulland. 2014. The past, present and future use of drifting fish aggregating devices (FADs) in the Indian Ocean. Marine Policy 45: 163-170.

Daw, T. 2008. How fishers' count: engaging with fishers' knowledge in fisheries science and management. $\mathrm{PhD}$ dissertation. Newcastle UK: Newcastle University.

De Carvalho, D., N. Gaspar, M. Keatinge and J. Guillen Garcia. 2018. The 2018 annual economic report on the EU Fishing Fleet. Scientific, Technical and Economic Committee for Fisheries (STECF, STECF18-07). Luxembourg: Publications Office of the European Union.

FAO. 2000. Biological characteristics of tuna. Text by Michel Goujon and Jacek Majkowski. In FAO Fisheries and Aquaculture Department [online]. Rome. Updated 2000. Available at http://www.fao.org/fishery/topic/16082/en [accessed May 10 2018] 
Fonteneau, A. 2014. On the movements and stock structure of skipjack (Katsuwonus pelamis). Document submitted to the IOTC. IOTC 2014-WPTT-16-36.

Froese R., S.F. Rainer and D. Pauly (eds). 2012. Tuna. Species in FishBase. http://www.fishbase.org January 2012 version[ accessed January 20 2018]

Fry, G. and S. Tarte (eds.). 2015. The new Pacific diplomacy. Suva: University of the South Pacific Press.

Gagern A. and J. van den Bergh. 2013. A critical review of fishing agreements with tropical developing countries. Marine Policy 38: 375-386.

Gegout, C. 2016. Unethical power Europe? Something fishy about EU trade and development policies. Third World Quarterly 37(12): 2192-2210.

Gillett, R. 2011. Tuna for tomorrow. Working Paper 11. Indian Ocean Commission and IOTC.

Giordano, M. 2003. The geography of the commons: the role of scale and space. Annals of the American Association of Geographers 93(2): 365-375.

Goulding, I. 2016. Research for PECH committee - Impact of fisheries partnership Agreements on employment in the EU and in third countries. European Parliament's Committee on Fisheries. Brussels: European Commission.

Government of Madagascar (GoMA) 2015. Law n 2015 - 053 of December $2^{\text {nd }} 2015$ regarding the Fishery and aquaculture Code. Art. 50, 51 and 54.

Government of Mauritius (GoMU). 2007. The Fisheries \& Marine Resources Act 2007. Art. 11, 21 and 25.

Government of Mauritius (GoMU). 2017. Annual Report on Performance. Fiscal Year 2016/17. Section 2.2. Status on implementation of budget measures for financial year 2016/2017.

Government of Seychelles (GoS). 2014. Fisheries Act 2014. Part III-Licensing requirements.

Havice, E. and L. Campling. 2013. Articulating upgrading: island developing states and canned tuna production. Environment and Planning A 45(11): 2610-2627.

Havice, E. and L. Campling. 2017. Where chain governance and environmental governance meet: interfirm strategies in the canned tuna global value chain. Economic Geography 93(3): 292-313.

Hicks, C.C. and J. Cinner. 2014. Social, institutional, and knowledge mechanisms mediate diverse ecosystem service benefits from coral reefs. Proceedings of the National Academy of Sciences 111(50): 1779117796.

Holland, M.B., and D. Lansing. 2017. Forests in limbo: assessing Costa Rica's forest and land reform policies. Society and Natural Resources 30(6): 738-749.

IOTC (Indian Ocean Tuna Commission), available at http://www.iotc.org/documents

- 2012. Report of the 15th Session of the IOTC Scientific Committee, Mahé, Seychelles, 10-15 December 2012. IOTC-2012-SC15-R[E]. p.38-41.

- 2014. Report of the 17th Session of the IOTC Scientific Committee. Mahé, Seychelles, 08-12 December 2014. IOTC-2014-SC17-R[E]. pp. 38-43 and 134-154.

- $\quad$ 2015. Report of the 18th Session of the IOTC Scientific Committee. Bali, Indonesia, 23-27 November 2015. IOTC-2015-SC18-R[E]. pp. 84-86.

- $\quad$ 2016. Report of the 20th Session of the Indian Ocean Tuna Commission. La Réunion, France. 23-27. May 2016. IOTC-2016-S20-R[E]: 114pp.

- 2016a. Report of the 19th Session of the IOTC Scientific Committee. Mahé, Seychelles, 01-05 December 2016. IOTC-2016-SC19-R[E]. pp. 40-45.

- $\quad$ 2017. Report of the 20th Session of the IOTC Scientific Committee. Mahé, Seychelles, 30 November4 December 2017. IOTC-2017-SC20-R[E]. pp. 115-117.

Kaplan, M., E. Chassot, J.M. Amandé, S. Dueri, H. Demarcq, L. Dagorn, and A. Fonteneau. 2014. Spatial management of Indian Ocean tropical tuna fisheries: potential and perspectives. ICES Journal of Marine Science 71(7): 1728-1749. 
Kaup, B. 2008. Negotiating through nature: The resistant materiality and materiality of resistance in Bolivia's natural gas sector. Geoforum 39: 1734-1742.

Kincaid, B.K. and G.R.H. Mahudi. 2014. Fishers' perception of a multiple-use marine protected area: why communities and gear users differ at Mafia Island, Tanzania. Marine Policy 43: 226-235.

Le Manach, F., C. Chaboud, D. Copeland et al. 2013a. European Union's public fishing access agreements in developing countries. PLoS ONE 8(11): e79899.

Le Manach, F., M. Andriamahefazafy, S. Harper, A. Harris, G. Hosch, G-M. Lange, D. Zeller and U. Rashid Sumaila. 2013b. Who gets what? Developing a more equitable framework for EU fishing agreements. Marine Policy 38: 257-266.

Le Manach, F. 2014. Past, present and future of publicly-funded European Union's fishing access agreements in developing countries. PhD Dissertation. Vancouver: University of University of British Columbia.

Lecomte, M., J. Rochette, Y. Laurans and R. Lapeyre. 2017. Indian Ocean tuna fisheries: between development opportunities and sustainability issues. IDDRI.

Macfadyen, G., B. Rohmer, B. Caillart. et al. 2015. Ex post evaluation of Union financial measures for the implementation of the Common Fisheries Policy and in the area of the Law of the Sea 2007-2013. Final report and annexes. Brussels: European Commission.

Mansfield, B. 2003. From catfish to organic fish: making distinctions about nature as cultural economic practice. Geoforum 34: 329-342.

Marsac, F., A. Fonteneau and P. Michaud. 2014. L'or bleu des Seychelles : histoire de la pêche industrielle au thon dans l'océan Indien. Marseille: IDR.

Miyake, M., P. Guillotreau, C.H. Sun and G. Ishimura. 2010. Recent developments in the tuna industry: stocks, fisheries, management, processing, trade and markets. FAO Fisheries and Aquaculture Technical Paper. No. 543. Rome, FAO. pp. 13-21

Mootoosamy, L., A. Sheikmamode, T. Sooklall and M.C. Mahadoo. 2017. Mauritius National Report to the Scientific Committee of the Indian Ocean Tuna Commission, 2017. IOTC-2017-SC20-NR17.

Myers, R. and C.P. Hansen. 2019 in press. Revisiting a theory of access: a review. Society and Natural Resources 1-21. https://doi.org/10.1080/08941920.2018.1560522

Neimark, B. 2010. Subverting regulatory protection of 'natural commodities': the Prunus Africana in Madagascar. Development and Change 41(5): 929-954.

Nikolic, N., A. Fonteneau, L. Hoarau, G. Morandeau, A. Puech and J. Bourjea. 2014. short review on biology, structure, and migration of Thunnus Alalunga in the Indian Ocean. IOTC. IOTC-2014-WPTmT05-13 Rev_2.

Obura, D. et al. 2017. Reviving the Western Indian Ocean economy: actions for a sustainable future. Gland: WWF International.

Pauly, D. and F. Le Manach. 2012. Expansion et impact de la pêche mondiale. Espèces 5: 54-61.

Peters, K. 2010. Future promises for contemporary social and cultural geographies of the sea. Geography Compass 4(9): 1260-1272.

Pew. 2011. Fish aggregating devices (FADs) and Tuna: impacts and management options. A report by the Pew CharitableTrust.

Pew. 2015. Estimating the use of FADs around the world, an updated analysis of the number of fish aggregating devices deployed in the ocean. Report by the Pew Charitable Trust.

Pew. 2016. Netting billions: a global valuation of tuna. Pew Charitable Trust.

POSEIDON, MRAG, NFDS and COFREPECHE. 2014. Review of tuna fisheries in the western Indian Ocean. In DG MARE (ed.). Framework contract MARE/2011/01 - Lot 3, specific contract 7. Brussels: DG MARE.

Razafimandimby, Y. and L. Joachim. 2016. Rapport National de Madagascar destiné au Comité Scientifique de la Commission des thons de l'Océan Indien, 2016. IOTC-2016-SC19-NR15. 
Ribot, J.C. 1998. Theorizing access: forest profits along Senegal's charcoal commodity chain. Development and Change 29: 307-341.

Ribot, J.C. and N.L. Peluso. 2003. A theory of access. Rural Sociology 68(2): 153-181.

Robbins, P. 2003. Political ecology in political geography. Political Geography 22(6): 641-645.

Robinson, J., J.E. Cinner and N.A.J. Graham. 2014. The influence of fisher knowledge on the susceptibility of reef fish aggregations to fishing. PLOS ONE 9(3).

Schurman, R.A. 1998. Tuna dreams: resource nationalism and the Pacific Islands' tuna industry. Development and Change 19: 107-136.

Schutter, M. and C. Hicks. 2019. Networking the Blue Economy in Seychelles: pioneers, resistance, and the power of influence. Journal of Political Ecology 26: 425-447.

Sellström, T. 2015. Africa in the Indian Ocean: islands in ebb and flow. Leiden: Koninklijke Brill.

Sikor, T., J. He and G. Lestrelin. 2017. Property rights regimes and natural resources: a conceptual analysis revisited. World Development 93: 337-349.

Sneddon, C. 2007. Nature's materiality and the circuitous paths of accumulation: dispossession of freshwater fisheries in Cambodia. Antipode 39(1): 167-193.

SFA 2010. Seychelles Fishing Authority' Fisheries Annual Report 2007-2010. Seychelles Fishing Authority. p. 23-27.

SFA 2016. Seychelles Fishing Authority's Fisheries Statistical Report of 2016, $1^{\text {st }}$ Semester. Seychelles Fishing Authority. p. 33, 52, 75, 86 and 97.

St Martin, K., B.J. McCay, G.D. Murray and T.R. Johnson. 2007. Communities, knowledge and fisheries of the future. International Journal of Global Environmental Issues 7(2): 221-239.

Sumaila, U.R., C. Bellmann and A. Tipping. 2016. Fishing for the future: an overview of challenges and opportunities. Marine Policy 69: 173-180.

Sumaila, U.R., V. Lam, F. Le Manach, W. Swartz and D. Pauly. 2016a. Global fisheries subsidies: an updated estimate. Marine Policy 69: 189-193.

Szaboova, L., K. Brown and J.A. Fisher. 2019. Access to ecosystem benefits: more than proximity. Society and Natural Resources 1-17. https://doi.org/10.1080/08941920.2018.1556759

Torres-Irineo, E., D. Gaertner, E. Chassot and M. Dreyfus-León. 2014. Changes in fishing power and fishing strategies driven by new technologies: the case of tropical tuna purse seiners in the eastern Atlantic Ocean. Fisheries Research 155: 10-19.

UNDP 2016. Human Development Report 2016: human development for everyone. New York: UNDP. Pp. 212-214.

USTA. 2017. Bulletin statistique thonier 2017 de l'Unité Statistique Thonière d'Antsiranana. Consulted at the USTA in October 2018.

Voyer, M., K. Barclay, A. McIlgorm and N. Mazur. 2017. Connections or conflict? A social and economic analysis of the interconnections between the professional fishing industry, recreational fishing and marine tourism in coastal communities in NSW, Australia. Marine Policy 76: 114-121.

Walker, B.L.E. and M.A. Robinson. 2009. Economic development, marine protected areas and gendered access to fishing resources in a Polynesian lagoon. Gender, Place and Culture 16(4): 467-484.

Walker, P.A. 2005. Political ecology: where is the ecology? Progress in Human Geography 29(1): 73-82.

Wolff, F-C., D. Squires and P. Guillotreau. 2013. The firm's management in production: management, firm, and time effects in an Indian Ocean tuna fishery. American Journal of Agricultural Economics 95(3): 547-567. 